good specimen of Hemiaster cf. asterias, Forbes, was obtained by a member of the party.

In the adjacent Gault pit at Dunton Green (which was not visited on this occasion) the Directors have obtained most of the above forms, and in addition: Belemnites ultimus, d'Orb., Belemnites attenuatus, Sow., Am. (Hoplites) denarius, Sow., Am. (Hoplites) splendens, Sow., Am. (Hoplites) tuberculatus, Sow., and Serpula sp. This pit shows a slightly greater thickness of Upper Gault.

After tea at "Ye Olde Bull," Otford, a vote of thanks was passed to the Directors, and the party returned to London. The Directors wish to acknowledge the courtesy of Mr. H. Wellband and Messrs. R. Iurtnell \& Sons in granting permission to visit their sections.

\title{
REFERENCES.
}

1889. Geol. Survey Map, I-jnch scale, Old Series, Sheet 6.

1855. Prestwich, J.- "On the Origin of Sand and Gravel Pipes in the Chalk of the London Tertiary District." Quart. Fourn. Geol. Soc., vol. $x i$.

1879. Price, F. G. Hilton - "The Gault." 8vo. London.

1886. SPURRELL, F. C.--"A Sketch of the History of the Rivers and Denudation of West Kent, etc." Report W. Kent Nat. Hist. Soc.

189r. Prestwich, Sir J.- "On the Age, Formation and Drift Stages of the Darent Valley." Quart. Gourn. Geol. Soc., vol. xlvii, pp. I26-163.

1897. KenNaRD, A. S.- "Excursion to Otford and Holmesdale Valley." Proc. Geol. Assoc., vol. xv, p. 209.

Ig07. ChandLer, R. H., and A. L. LEach.-" Excursion to Dartford Heath." Proc. Geol. Assoc., vol xx, p. I22.

I907. BENNETT, F. J.- - Ightham" (in the "Homeland" Series).

Ig09. TREACHER, L., and P. A. B. MARTIN.- "Excursion to Limpsfield and Westerham." Proc. Geol. Assoc, vol. xxi, p. 59.

\section{EXCURSION TO MAIDSTONE, AND THE WILLINGTON AND LOOSE VALLEYS.}

\author{
Saturday, July ioth, rgog.
}

Director: F. J. Bennett, F.G.S. (late H.M. Geol. Survey).

Exiursion Secretary: T. W. REAder.

(Report by THE DTRECTOR.)

AfTER some delay in getting extra conveyances, as more members came than were expected, 23 drove to Willington Schools and were met there by Mr. Allcorn, keeper to G. Marsham, Esq., D.L., T.P.

Willington or Otham Caves were first inspected, then some of the principal "Swallow". Holes in the Willington or Otham Valley. All could not be seen, as that valley is thickly wooded. 
It was seen that some of the holes hold water, while others were dry.

Of those with water, the large one almost at the head was nearly fuil, and is never dry, though largely pumped from to wash the hops grown near it.

The Director gave his view that this valley was once under artesian conditions and once capped by Sandgate Beds, traces of which remain ;* that long prior to any visible stream, one underground had been doing denuding work, mechanical and chemical; this had caused subsidence sufficient to initiate a channel for a visible stream. This had cut through the impervious cover to places of weakness, the "Swallow" Holes now seen there ; that up these for a time during a high-water level water had risen. Then through some cause the bulk of the water seems, suddenly perhaps, to have left the valley, leaving it in its present incompleted stage, perhaps a unique example of the kind.

The caves at the end of the valley seem due to water action, as in the case of limestone caves in other limestone areas, and left high and dry after the lowering of a once much higher water-level. Some of these caves may have been caverns, and connected, as one now certainly is, with those in the Mote Park, which it was not possible to visit on this occasion. These caves, which the Director has seen, are now in the condition of old quarries and correspond with those visited, beginning not far from where the "Swallow" Holes end. The Director pointed out that where the caves ceased a kind of cañon terminated the Willington Valley, at the bottom of which was a spring-pond, always full, and once perhaps, as the evidence, not seen that day, seems to indicate, the bottom of a "Swallow" Hole. The water in the upper Swallow Hole is perhaps connected underground with that in the spring-pond.

Rain fell heavily before the upper water-filled Swallow Hole could be fully examined, and the members took lunch at the Bell Inn. It was now seen that all attempts to follow out the programme and to visit Leeds and the First Stage Swallow Holes, viz., those on the water-shed between Loose and Len Valleys, must be abandoned. After lunch the party drove on to the Brishing Court section of the Loose Valley. Before visiting this we were kindly met by Mr. W. Skinner, and the deep crater-shaped and Second Stage Swallow Hole called Pit-land, which nearly swallowed some of the party, was investigated by the adventurous section.

Mr. Skinner then led the way to the fine old timbered-farm house, Brishing Court, and the Director was asked to make a few explanatory remarks as to what remained to be seen. It was difficult to put all he wished before them, as the programme had been altered and his original intention to have walked

* See Prestwich, "Water-bearing Strata of the Country around London," p. r $3^{2}$.

Proc. Geol, Assoc., Vol. XXI, PART 4, Igog.] 
through the Mote Park frustrated; this would have saved time and have given a better grasp of the situation, and the Leeds portion, not seen, would have aided also a fuller comprehension of a complicated condition of valley formation of which the Swallow Holes were, in the view of the Director, important factors, and these boles were perbaps better preserved and more numerous here than in any other instance. Varying and inconstant water action he considered also helped to form them. An example of this was then visited, where the Loose could be seen to be flowing two distinct ways at the same time, and part of this stream was said to issue to the south into the Beult Valley by an underground course.

The Swallow Hole was then visited, along the bottom of which the stream could be seen to flow, disappearing after a very short course.

The Director then pointed out the fine example of an interrupted valley they were walking along, coinciding with the disappearance of the stream. The valley here was completely lost, and any semblance of one was due to artificial causes, viz., to long-continued quarrying, perhaps dating back to Roman times.

After a very pretty walk over the deep buried stream, the next glimpse of this was seen in Mr. Atkins' garden at Boughton Quarries, the stream issuing at the foot of a high bank. With the appearance of the stream the valley once more appeared, as was seen higher up, above where the first loss occurred by Brishing Court.

Then the final loss and reappearance of the stream was visited, it again appearing at the foot of a steep elevation marking another interruption of the valley.

Here Mr. Foster Clarke, who owns this part of the Loose, met the party, and a conversation took place as to the best methods of tracing underground water, an effort to trace which here Mr. Clarke had made.

It was noted that there was more water issuing at the last loss of the Loose than is the case in that part flowing through Mr. Atkins' garden, indicating additions from other underground sources.

The great beauty of this part of the valley was admitted by all, and quite enough was seen to make those present wish to see much more of a most interesting and certainly most uncommon area.*

\footnotetext{
* In support of my views I would quote what has only lately come under my notice from Prestwich's "'Nater-Bearing Strata of London," p. 132: "It also further appears that the underground waters very commonly tend to take a course corresponding in a great measure with that of the waters aboveground; that streams and rivers may be considered as representing, in definite lines on the surface, a water. flow agreeing in its general direction with that which takes place, bodily, in the strata below. M. D'Archix, who has paid great attention to the suoject of the water-bearing strata of the Tertiary and Cretaceous Series of France, confirms, as the result of his experience, the rule laid down on perfectly independent grounds by the Abbé Paramelle, in his observation of springs, viz., "That the subterranean currents of water follow the same litw (with reference to their course) as those which fiow on the surface." F. J.B., 8, ix, iso...
} 
Proc. Geol. Assoc., Vol. XXI.

Plate IX.

Sketch-map of the country around Otham and Leeds, Kent, showing a new Swallow-hole Area in the Hythe Beds, with Valleys initiated by the Swallow-hores.

In three stages: First, those four by Langley Hole on the water shed; second, those within Loose and Len Valleys thirty-four; third, those along the bottom, as in Willington Valley, with thirteen. The Loose and the Valley too is lost at; Boughton Quarries. Some
water also escaping underground and into Beutt Valley.
(Repreduced by termission o, the Council of the Royal (icosraflicai. Sciety). From recent Sưrvey by F. J. Benñelt, F.G.S.

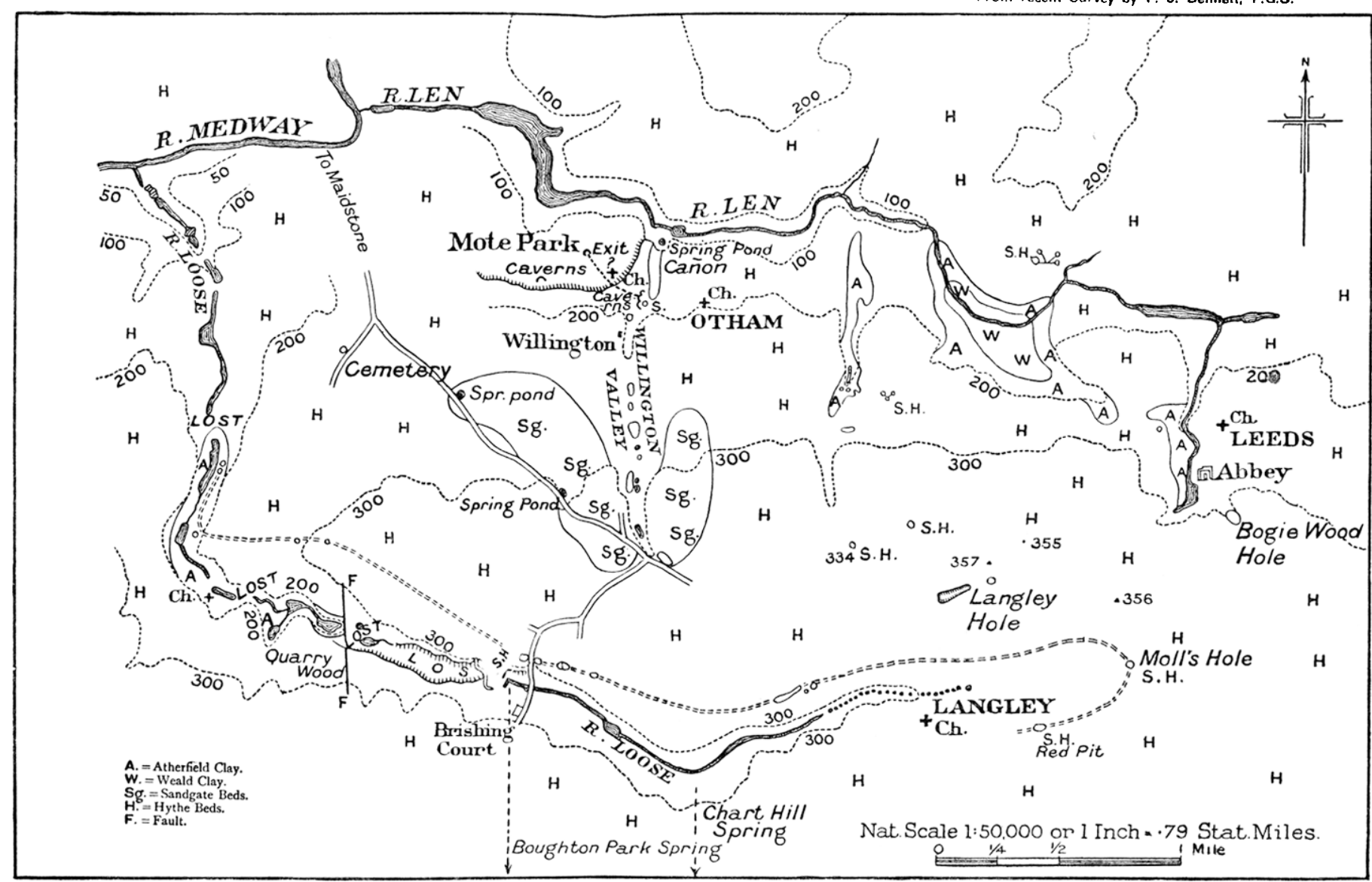

To face prage 242 
The President then thanked the Director and also Messrs. W. Skinner and Foster Clarke, who had so kindly met and had placed all their valuable local knowledge at the disposal of the Association.

Full justice was done to a substantial tea at the Bank Restaurant, Maidstone, after which some of the party returned to London by the 6.26 train, whilst others remained to visit the museum and other objects of interest in the town.

\title{
EXCURSION TO NORTHWOOD AND CROXLEY GREEN.
}

\author{
Saturday, JULy 24TH, 1909. \\ Director: H. Kidner, F.G.S. \\ Excursion Secretary: A. C. Young.
}

(Report by THE DIRECTOR.)

ABout 20 nembers travelled from Marylebone (Great Central Railway) by the 2.I5 train, arriving at Northwood about 2.45 . Rain, which had been falling heavily, cleared off about the time of starting, and the remainder of the day was perfectly fine. At the Northwood Company's Brickfield, which had not been visited previously by the Association, a section was seen in the lower part of the London clay; the beds being in descending order: brown clay $3 \mathrm{ft}$, a pebble bed 6 in., and sandy clay (BasementBed) $5^{\frac{1}{2}} \mathrm{ft}$. in thickness. The Basement-Bed was calcareous, especially in the upper part, and a calcareous band I in. thick was pointed out about a foot below the bed of pebbles. Calcareous fossiliferous nodules were numerous in the BasementBed, some of large size. Many nodules full of fossils were seen in the pit. The fossils obtained included Panopaa intermedia, Cyprina morrisii, Cyrena, etc., from the nodules; a shark's tooth from the pebble bed; and one of the nodules contained a fossil crab, the claws showing on the outside. Dr. A. Morley Davies, who was present, made a few remarks on the fossils of the Basement-Bed, and stated that Hemiaster forbesi, J. W. Gregory* (previously recorded only from Pinner), and Ophiura zetherelli (?) (not hitherto recorded from the Basement-Bed) have been obtained from this pit. Apparently there was no band of pebbles at the bottom of the Basement-Bed. The floor of the pit consisted of tenacious marly clay, about $2 \mathrm{ft}$. thick, forming the top of the Reading Beds, and passing into mottled clay below.

\footnotetext{
* Brit. Cainozoic Echinoidea, Proc. Geol. Assoc., vol. xii, pp. I6-6o (July, I89i).
} 